\title{
ANALISIS PROYEKSI KESEMPATAN KERJA DAN PRODUKTIVITAS TENAGA KERJA DI KABUPATEN LOMBOK BARAT 2010 - 2025
}

\author{
Oleh: \\ Muhammad Hendra Djunaedi \\ Staff Dinas Pekerjaan Umum NTB \\ E-mail/No. Hp: - /0817537263
}

\begin{abstract}
This research takes headline about opportunity forecast analysis of activity opportunity and labour productivity in Kabupaten Lombok Barat 2010-2025. Analytical technique applied in studying this research is exponential trend analytical method depicting an movement of uptrend or downwards on a long term obtained from average of alteration from time to time and its(the value enough flattening ( smooth) From here can be suggested that, Local Government Level Of II Kabupaten Lombok Barat need determine target which must be reached that observation of developer of business field sectors capable to can be made balance to with improvement of its(the labour productivity.
\end{abstract}

Keywords: Forecasting, activity Opportunity, Productivity, Labour

\section{PENDAHULUAN}

Salah satu prioritas pembangunan nasional sebagaimana diamanatkan oleh program pembangunan nasional (Propenas) 2005-2009 yakni di bidang sumber daya manusia, prioritas tersebut dicapai melalui upaya-upaya pokok sebagai berikut. Pertama, mengendalikan jumlah dan laju pertumbuhan penduduk dengan meningkatkan pelayanan kesehatan reproduksi, termasuk Keluarga Berencana, serta memberdayakan keluarga dan masyarakat menuju terbentuknya keluarga kecil yang berkualitas.

Dengan kebijakan pembangunan daerah, persebaran dan mobilitas penduduk didorong agar lebih seimbang sesuai dengan daya dukung wilayah. Kedua, meningkatkan akses dan pemerataan pelayanan pendidikan yang bermutu di berbagai jenjang. Pendidikan anak dini usia didorong dalam rangka menumbuhkembangkan anak dan meningkatkan kesiapan anak masuk sekolah;

Pendidikan dasar sembilan tahun ditingkatkan sehingga seluruh anak usia 7 - 15 tahun dapat memperoleh pendidikan setidak-tidaknya sampai jenjang sekolah menengah pertama dengan APK sekitar 95 persen pada tahun 2008; pendidikan menengah diperluas baik umum maupun kejuruan untuk mengantisipasi meningkatnya lulusan sekolah menengah pertama sebagai hasil dari pelaksanaan Wajib Belajar Pendidikan Dasar Sembilan Tahun; serta pendidikan tinggi ditingkatkan untuk memenuhi kebutuhan pasar kerja dan pengembangan ilmu pengetahuan dan teknologi. Disamping itu, kualitas tenaga kerja sesuai keahlian, profesionalisme, dan kompetensinya ditingkatkan untuk memenuhi kebutuhan pasar kerja yang dinamis.

Sasaran umum pembangunan ekonomi adalah meningkatnya 
pertumbuhan ekonomi secara bertahap antara $5-6$ persen; laju inflasi antara $5-$ 6 persen; terciptanya lapangan kerja yang memadai bagi penurunan pengangguran; serta berkurangnya jumlah penduduk miskin.

Perlu diketahui pula bahwa dalam tahun 2004, setiap 1 persen pertumbuhan ekonomi menciptakan lapangan kerja baru sekitar 181.000. Pada tahun 2005, kemampuan menciptakan lapangan kerja baru menurun menjadi 49.000, antara lain karena ketidakstabilan ekonomi, dan pada tahun 2006 meningkat kembali menjadi 265.000 per 1 persen pertumbuhan ekonomi. Dengan kemampuan ini, total lapangan kerja baru yang tercipta sekitar 0,9 juta pada tahun 2004, kemudian menurun menjadi 0,3 juta pada tahun 2005, dan meningkat menjadi 1,5 juta pada tahun 2006 .

Sementara itu, dalam periode yang sama, angkatan kerja bertambah 1,3 juta, 1,9 juta, dan 0,5 juta. Dengan lapangan kerja dan tambahan angkatan kerja baru tersebut, pengangguran terbuka pada tahun 2004 menjadi 10,3 juta $(9,9$ persen dari total angkatan kerja) dan tahun 2005 menjadi 11,9 juta (11,2 persen). Dalam tahun 2006, kondisi ketenagakerjaan membaik dengan pengangguran terbuka menurun menjadi 10,9 juta $(10,3$ persen), penurunan yang pertama kalinya sejak tahun 2000.

Gambaran di atas menunjukkan bahwa angka pengangguran tidak saja ditentukan oleh lapangan kerja baru yang tercipta, tetapi juga oleh tambahan angkatan kerja baru yang masuk ke pasar tenaga kerja yang besarnya cukup fluktuatif. Hubungan antara penggerak dan sektor ekonomi dengan penciptaan lapangan kerja agak sedikit rumit. Ekonomi tahun 2004 yang, meskipun hanya tumbuh 5,0 persen tetapi didukung oleh investasi, mendorong sebagian tenaga kerja berpindah dari sektor pertanian ke sektor perdagangan.
Dalam tahun 2005, sebagian tenaga kerja berpindah lagi ke sektor pertanian dan sebagian lainnya ke sektor industri pengolahan. Pertambahan tenaga kerja pada sektor industri pengolahan pada tahun 2005 antara lain karena pengaruh investasi yang cukup tinggi pada tahun 2004 hingga triwulan III2005. Dinamika ekonomi berpengaruh terhadap pergerakan tenaga kerja antarsektor ekonomi.

Salah satu permasalahan utama yang berpotensi menghambat pembangunan di Kawasan Timur Indonesia adalah masih rendahnya kualitas dankapasitas sumberdaya manusia yang menyebabkan tingginya jumlah pengangguran dan rendahnya kemampuan untuk menciptakan kesempatan kerja sendiri melalui kewirausahaan. Disisi lain pelaku pembangunan sudah mengembangkan dukungan-dukungan dalam memperkuat program pemberdayaan masyarakat. Salah satu program ketenagakerjaan yang dikembangkan oleh pemerintah adalah program pemberdayaan masyarakat dengan fokus peningkatan gerakan kewirausahaan masyarakat pedesaan dan miskin kota. Belum lagi kalau melihat program yang dikembangkan oleh swasta ataupun LSM internasional.Kompleksnya masalah ketenagakerjaan ini merupakan bagian integral dari masalah ekonomi. Dengan demikian perencanaan ekonomi harus mencakup perencanaan ketenagakerjaan.

Berdasarkan hasil Susesnas 2004 diketahui bahwa dari jumlah penduduk NTB sebanyak 4.127.519 jiwa, yang merupakan penduduk usia kerja ( 10 tahun keatas) sebanyak 3.223.592 jiwa atau $78,1 \%$, termasuk didalamnya angkatan kerja sebanyak 2.088.890 orang.

Kemudian dari hasil sensus penduduk tahun 2005, penduduk NTB tercatat 4.143.292 jiwa dengan 
kepadatan penduduk mencapai 205 jiwa $/ \mathrm{km}^{2}$, dari jumlah tersebut 3 .223 .592 orang diantaranya berusi 15 tahun keatas atau disebut penduduk usia kerja , sedangkan penduduk usia kerja yang aktif bekerja maupun sedang mencari pekerjaan atau disebut sebagai angkatan kerja berjumlah 2.705.556 orang dimana 1.940 .578 orang $(71,72 \%)$ diantaranya terserap didalam kegiatan ekonomi/bekerja, sedangkan 148.442 orang $(28,28 \%)$ lainnya berstatus mencari pekerjaan/ menganggur.Jumlah penduduk usia kerja pada tahun 2006 sebanyak 3.223.592 orang, jumlah pencari kerja terdaftar sebanyak 14.753 orang, jumlah lowongan kerja terdaftar sebanyak 7.107 orang. Sedangkan pencari kerja yang ditempatkan sebanyak 5.245 orang.

Angka Penggangguran terbuka di NTB pada tahun 2006 mencapai 148.442 orang terdiri dari 42,8 persen perempuan dan 57,2 persen laki-laki. Disamping itu, yang lebih memperihatinkan adalah struktur penganggur yang didominasi oleh golongan kelompok umur produktif.Terbatasnya kesempatan kerja lokal dan rendahnya tingkat keterampilan kerja, menimbulkan kompleksitas yang tinggi dalam penanganan tenaga kerja. Penyediaan lapangan kerja baru berbanding terbalik dengan penambahan jumlah pencari kerja baru, terutama lulusan SMTA dan sarjana yang meningkat tajam setiap tahunnya. Padahal NTB memiliki potensi lapangan kerja yang beragam bila dikelola dengan baik.

Pembinaan tenaga kerja merupakan tugas dan tangggungjawab semua pihak, serta menuntut penyelesaian dalam jangka pendek maupun jangka panjang. "Pendidikan dan keterampilan kerja sesungguhnya merupakan investasi masa depan. Oleh karena itu, pola dan strategi pembinaan terhadap angkatan kerja usia produktif, perlu mendapatkan perhatian yang sungguh-sungguh dalam pola keterpaduan yang lebih profesional, sehingga angkatan kerja usia produktif mampu bersaing dan mengisi setiap kesempatan kerja yang ada dalam upaya membangun perekonomian diri, daerah dan bangsanya.

Pembangunan ketenagakerjaan di Kabupaten Lombok Barat, diarahkan dalam rangka perluasan lapangan kerja dan mengurangi penggangguran serta peningkatan sumber daya manusia demi terbentuknya tenaga kerja profesional yang mandiri, produktif, berjiwa usaha, berkualitas, terampil, efisien dan efektif terutama bagi angkatan kerja muda, sehingga mampu mengisi, menciptakan dan memperluas lapangan kerja serta kesempatan berusaha.

Dengan langkah-langkah diatas diharapkan dapat membuka kesempatan yang luas bagi pencari kerja untuk mengisi lowongan-lowongan kerja yang tersedia dan mendapat pekerjaan yang selayaknya sehingga dapat meningkatkan pendapatan mereka dan pada akhirnya akan terwujud struktur perekonomian yang seimbang. Selain itu Lombok Barat memiliki potensi cagar wisata terhampar luas yang jika dikelola dengan baik maka pengangguran ataupun TKI ilegal tidak banyak terjadi. Berdasarkan latar belakang yang telah diurakan, maka perumusan masalah yang diambil adalah 1) Seberapa besar laju pertumbuhan ekonomi dilihat dari PDRB Kabupaten Lombok Barat tahun 1997 2006. 2) Seberapa besar laju pertumbuhan tenaga kerja di Kabupaten Lombok Barat tahun 1997 - 2006. 3)Seberapa besar laju kesempatan kerja di Kabupaten Lombok Barat tahun 1997 - 2006. 4) Seberapa besar proyeksi kesempatan kerja dan produktivitas tenaga kerja di Kabupaten Lombok Barat tahun $2010-2025$ ? 


\section{TINJAUAN PUSTAKA}

Kesempatan kerja adalah jumlah yang menunjukan berapa orang yang telah atau dapat tertampung dalam suatu perusahaan. Kesempatan kerja dapat diwujudkan dengan tersedianya lapangan kerja yang memungkinkan dilaksanakannya bentuk aktivitas yang dinamakan bekerja tesebut. Dengan demikian kesempatan kerja dapat diartikan sebagai permintaan atas tenaga kerja.

Penciptaan kesempatan kerja adalah langkah yang tepat, mengingat penawaran tenaga kerja yang lebih tinggi dari permintaanya. Kelebihan tenaga kerja yang lebih tinggi dari permintaanya. Kelebihan tanaga kerja ini biasanya merupakan tenaga kerja tidak ahli, sehingga tidak perlu kiranya perluasan investasi pada proyek-proyek padat karya, bukan pada perkembangan sektor kapitalitas dengan cirri utama padat modal sebagai hasil dari pilihan strategis pembangunan yang mendahulukan pertumbuhan ekonomi yang tinggi.

Penduduk yang bekerja terserap dan tersebar di berbagai sector, namun tiap sektor mengalami pertumbuhan yang berbeda demikian juga kemampuan tiap sektor berbeda dalam menyerap tenaga kerja. Perbedaan laju pertumbuhan tersebut mengakibatkan dua hal, yaitu 1)Terdapat perbedaan laju peningkatan produktivitas kerja masingmasing sektor. 2)Secara berangsurangsur terjadi perubahan sektoral, baik dalam penyerapan tenaga kerja maupun dalam kontribusinya terhadap pendapatan nasional.

Perbedaan laju perumbuhan pendapatan nasional dan kesempatan kerja tersebut juga menunjukan perbedaan elastisitas masing-masing sector untuk penyerapan tenaga kerja. Elasitisitas kesempatan kerja didefinisikan sebagai perbandingan laju pertumbuhan kesempatan kerja dengan laju pertumbuhan ekonomi. Elastisitas tersebut dapat digunakan untuk seluruh perekonomian atau untuk masing-masing sektor atau sub sektor. Jadi:

$\mathrm{E}=\frac{\Delta \mathrm{N} / \mathrm{N}}{\Delta \mathrm{Y} / \mathrm{Y}}$

Untuk masing-masing sektor, dan untuk masing-masing subsektor adalah sebagai berikut:

$\mathrm{E} i=\frac{\Delta \mathrm{N} i / \mathrm{N} i}{\Delta \mathrm{Y} i / \mathrm{Y} i}$

Dimana :

$\Delta \mathrm{N} / \mathrm{N}=$ Laju Pertumbuhan Kesempatan Kerja

$\Delta \mathrm{Y} / \mathrm{Y}=$ Laju Pertumbuhan Pendapatan Nasional

Konsep elastisitas ini dapat digunakan untuk memperkirakan pertambahan kesempatan kerja. Bila laju pertumbuhan kesempatan kerja dinyatakan dengan $\mathrm{k}$ dan laju pertumbuhan PDB (Produk Domestik Bruto) dinyatakan dengan $\mathrm{g}$, maka dapat diajukan rumus sebagai berikut:

$$
\mathrm{K}=\mathrm{e} \times \mathrm{g}
$$

Atau laju pertumbuhan kesempatan kerja k, sama dengan elastisitas kesempatan kerja E, dikalikan dengan laju pertumbuhan PDB (Produk Domestik Bruto). Konsep elastisitas ini dapat digunakan untuk memperkirakan kebutuhan tenaga untuk suatu periode tertentu, atau untuk menyusun simulasi kebijakan pembangunan untuk ketenagekerjaan yaitu dengan memilih beberapa alternaif laju pertumbuhan tiap sektor, maka dihitung kesempatan kerja yang dapat diciptakan (Simanjuntak, 1985:82-83).

Menurut Soeharto Sagir $(1993 ; 239)$ di Indonesia kesempatan kerja yang ada dibagi menjadi 11 sektor yang disebut Kelompok Lapangan Usaha Indonesia (KLUI), yang terdiri dari 1) Sektor Pertanian, Perkebunan, 
Perhutanan, Peternakan dan Perikanan; 2) Sektor Pertambangan dan Galian; 3) Sektor Industri; 4) Sektor Gas, Air dan Listrik; 5) Sektor Bangunan dan Konstruksi; 6) Sektor Perdagangan, Restoran dan Hotel; 7) Sektor Transportasi dan Komunikasi; 8) Sektor Bank dan Lembaga Keuangan lainnya; 9) Sektor Sewa Rumah; 10) Sektor Pemerintah dan Hankam; 11) Sektor Jasa.

Dari sebelas sektor diatas yang paling banyak memberikan kesempatan kerja adalah sektor pertanian, oleh karena itu Indonesia terkenal dengan sebutan negara agraris karena sektor pertanian adalah sektor yang paling menonjol.

Tetapi pertanian ini tidak selamanya dijadikan andalan untuk menyediakan kesempatan kerja karena lahan pertanian tidak mungkin dapat bertambah bahkan selalu berkurang untuk dijadikan lahan perumahan.

Produktivitas mengandung pengertian filosofis, menurut Payaman J. Simanjuntak (1985:30), secara filosofis Produktivitas mengandung pandangan hidup dan sikap mental yang selalu berusaha untuk meningkatkan mutu kehidupan. Keadaan hari ini harus lebih baik dari kemarin, dan mutu kehidupan besok lebih baik dari hari ini. Hal ini akan mendorong manusia untuk tidak cepat merasa puas, akan tetapi terus mengembangkan diri dan meningkatkan kemampuan kerja. Untuk definisi kerja, produktivitas merupakan perbandingan antara hasil yang dicapai (keluaran) dengan keseluruhan sumber daya (masukan) yang dipergunakan per satuan waktu. Definisi kerja ini mengandung cara atau pengukuran.

Pengertian teknis operasional mengandung makna penningkatan produktivitas yang terwujud dalam empat bentuk, yaitu Jumlah produksi yang sama dapat diperoleh dengan menggunakan sumber daya yang lebih sedikit, Jumlah produksi yang lebih besar dapat dicapai dengan menggunakan sumber daya yang lebih sedikit, Jumlah produksi yang lebih besar dapat dicapai dengan menggunakan sumber daya yang sama, Jumlah produksi yang jauh lebih besar dapat diperoleh dengan pertambahan sumber daya yang relative lebih kecil.

Sumber daya masukan dapat terdiri dari beberapa faktor produksi, seperti tanah, gedung, mesin, peralatan bahan mentah dan sumber daya manusia itu sendiri. Prpduktivitas masing - masing faktor produksi tersebut dapat dilakukan baik secara bersama - sama maupun secara berdiri sendiri. Dalam hal ini peningkatan produktivitas manusia merupakan sasaran strategis karena peningkatan produktivitas faktor - faktor lain sangat tergantung pada kemampuan tenaga manusia yang memanfaatkannya.

Dengan pendekatan system, faktor yang mempengaruhi produktivitas karyawan dapat digolongkan pada tiga kelompok (Simanjuntak, 1985: 30-33), yaitu 1)Yang menyangkut kualitas dan kemampuan fisik karyawan, antara lain: pendidikan, latihan, etos kerja, motivasi kerja, sikap mental dan fisik. 2)Sarana pendukung antara lain: yang pertama, lingkungan kerja (termasuk tekonologi dan cara produksi, sarana dan peralatan produksi yang dipergunakan, tingkat keselamatan dan kesehatan kerja serta suasana dalam lingkungan kerja sendiri). Kedua, menyangkut kesejahteraan yag tercermin dalam system pengupahan dan jaminan social, serta jaminan kelangsungan kerja. 3)Supra sarana, antara lain kebijaksanaan pemerintah, hubungan industrial dan manajemen.

\section{METODE PENELITIAN}

Dalam penelitian ini penulis menggunakan jenis Deskriftif Kuantitatif yaitu penyajian dari materi yang didapat 
sebagai hasil penelitian dengan memberikan gambaran uraian atau data apa adanya sesuai dengan kenyataan yang ada.

Data yang digunakan dalam penelitian ini time series dari tahun 1997-2006 dan 2007. Menggunakan metode tren ekponensial : growth)

$P_{n}=P_{0} e^{r n}$ (eksponensial rate of

Dimana, Pn: Jumlah Penduduk pada tahun n; Po: Jumlah Penduduk pada tahun awal; r: Angka pertumbuhan; n: Jangka waktu dalam tahun; e: bilangan pokok dari sistem logaritma natural yang besarnya sama dengan 2,7182818 .

\section{Metode pertumbuhan Geometric$$
P_{n}=P_{0}(1+r)^{n}
$$$$
\text { Keterangan }
$$

Dimana, Pn: Jumlah Penduduk pada tahun n; Po: Jumlah Penduduk pada tahun awal; r: Angka pertumbuhan; n: Jangka waktu dalam tahun.

Catatan :

$\mathrm{P}$ dapat diganti dengan:

AK: Angkatan Kerja dan AKT (Angkatan Kerja Tertampung); atau KK: Kesempatan Kerja

Dalam mempermudahkah penghitungan maka peneliti menggunakan software analisis yang bernama MINITAB 11 for Windows. Metode yang dipergunakan untuk menghitung data adalah metode Exponensial Trend Analysis. Metode ini digunakan untuk menghitung proyeksi kesempatan kerja dengan tahun dasar 1997-2006.

Untuk mengetahui Produktivitas Sektoral :

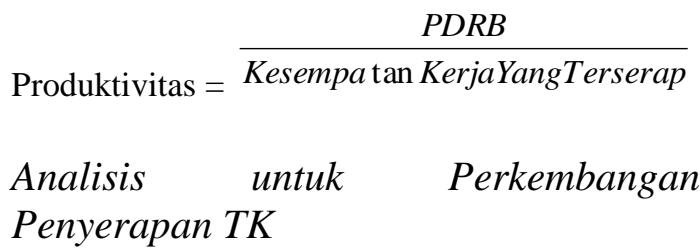

$$
G_{T K}=\frac{\sum T K_{t}-\sum T K_{t(-1)}}{\sum T K_{t(-1)}} \times 100 \%
$$

Dimana, $G_{T К}=$ Perumbuhan TK pada Periode t; $\sum T K_{t}=$ Jumlah TK Pada Periode $\mathrm{t} ; \quad \sum T K_{t(-1)}=$ Jumlah $\mathrm{TK}$ Sebelum Periode t.

Menurut Nasution ( $2003: 30-31$ ), Ukuran akurasi hasil peramalan yang merupakan ukuran kesalahan merupakan ukuran tentang tingkat perbedaan anatara peramalan dengan permintaan yang sebenarnya terjadi. Ukuran yang biasa digunakan, yaitu :

$$
\text { Rata - rata Deviasi Mutlak (Mean }
$$
Absolute Deviation = MAD ), MAD merupakan rata-rata kesalahan mutlak selama periode tertentu tanpa memperhatikan apakah hasil peramalan lebih besar atau lebih kecil dibandingkan kenyataannya. Secara matematis, MAD dirumuskan sebagai berikut :

$$
M A D=\sum\left|\frac{A_{t}-F}{n}\right|
$$

Dimana :

$\mathrm{A}=$ Permintaan aktual pada periode $\mathrm{t}$

$\mathrm{Ft}=$ peramalan permintaan (Forecast) pada periode $\mathrm{t}$

$\mathrm{n}=$ Jumlah periode peramalan yang terlihat

Rata - Rata Kuadrat Kesalahan (Mean Square Error = MSE), MSE dihitung dengan menjumlahkan kuadrat semua kesalahan peramalan pada setiap periode dan membaginya dengan jumlah periode peramalan. Secara sistematis, MSE dirumuskan sebagai berikut :

$$
M S E=\sum \frac{\left(A_{t}-F_{t}\right)}{n}
$$

Rata - rata Persentase Kesalahan Mutlak ( Mean Absolute Percentage Error = MAPE ), MAPE merupakan ukuran kesalahan relatif, MAPE biasanya lebih berarti dibandingkan 
MAD karena MAPE menyatakan persentase kesalahan hasil peramalan terhadap permintaan permintaan aktual selama periode tertentu yang akan memberikan informasi persentase kesalahan terlalu tinggi atau terlalu rendah. Secara sistematis, MAPE dinyatakan sebagai berikut :

$$
\text { MAPE }=\left(\frac{100}{n}\right) \sum\left|A_{t}-\frac{F_{t}}{A_{t}}\right|
$$

\section{PEMBAHASAN}

Perluasan kesempatan kerja adalah suatu hal yang sangat penting untuk dilakukan setiap daerah yang sedang membangun, mengingat jumlah penduduk maupun angkatan kerja yang bukannya semakin berkurang tetapi semakin bertambah meskipun telah ditekan dengan program keluarga berencana.

Hal ini merupakan suatu keharusan sehingga kebijaksanaan yang menyangkut perluasan kesempatan kerja sektoral maupun kebijaksanaan yang berkaitan untuk menunjang perkembangan sektorsektor lapangan usaha perlu diprioritaskan, sehingga terjadi keseimbangan antara kewajiban untuk turut berpartisipasi dalam pembangunan dan hak untuk ikut menikmati hasil pembangunan tersebut. Dalam menghitung angkaangka dalam proyeksi tenaga kerja ini, penulis menggunakan asumsi bahwa kondisi daerah dalam keadaan tetap (cateris paribus).

Perhitungan perkiraan jumlah kesempatan kerja di Kabupaten Lombok Barat ini menggunakan software pengolahan data MINITAB 11 for windows yang menghasilkan data dalam tabel 12 atau menggunakan rumus dasar pertumubuhan, yaitu :

$\mathrm{KK}_{\mathrm{n}}=\mathrm{KK}_{0}(1+\mathrm{r})^{\mathrm{n}}$
Keterangan :

$\mathrm{KK}_{\mathrm{n}}$ : Jumlah kesempatan kerja pada tahun $\mathrm{n} ; \mathrm{KK}_{0}$ : Jumlah kesempatan kerja pada tahun dasar; r: Tingkat Pertumbuhan; n: Jangka waktu.

\section{Catatan :}

Tahun dasar adalah tahun 2006. Tingkat pertambahan rata-rata untuk sektor pertanian sebesar $4,22 \%$. Tingkat pertambahan rata-rata untuk sektor pertambangan sebesar 2,93\%. Tingkat pertambahan rata-rata untuk sektor Industri sebesar $-0,62 \%$. Tingkat pertambahan rata-rata untuk sektor listrik sebesar $-3,38 \%$. Tingkat pertambahan ratarata untuk sektor bangunan sebesar $4,02 \%$. Tingkat pertambahan rata-rata untuk sektor perdagangan sebesar $0,50 \%$. Tingkat pertambahan rata-rata untuk sektor angkutan dan perhubungan sebesar $4,18 \%$.

Tingkat pertambahan rata-rata untuk sektor keuangan sebesar 10,69\% Tingkat pertambahan rata-rata untuk sektor jasa dan lain-lain sebesar -3,01.

Dari hasil pengolahan data tersebut dapat diketahui bahwa pada tahun 20102025, perluasan kesempatan kerja di Kabupaten Lombok Barat masih diduduki oleh sektor pertanian, sehingga untuk 2025 tahun mendatang perkiraan jumlah sektor pertanian mencapai 262.054 jiwa disusul sektor perdagangan, sektor konstruksi, sektor komunikasi dan sektor keuangan yang masing-masing diperkirakan kesempatan kerjanya mencapai sektor perdagangan 41.722 jiwa, 50.420 jiwa sektor konstruksi, 48.184 untuk komunikasi dan 10.166 jiwa sektor keuangan. Keempat sektor ini mengalami kecenderungan naik atau tren yang diperoleh positif. Sedangkan untuk sektor lainnya mengalami penurunan atau tren yang dihasilkan adalah negatif seperti sektor industri, sektor jasa dan sektor listrik yang mengalami penurunan jumlah kesempatan kerjanya. 
Tabel 1. Perkiraan Jumlah Kesempatan Kerja di Kabupaten Lombok Barat Tahun 2010-2025

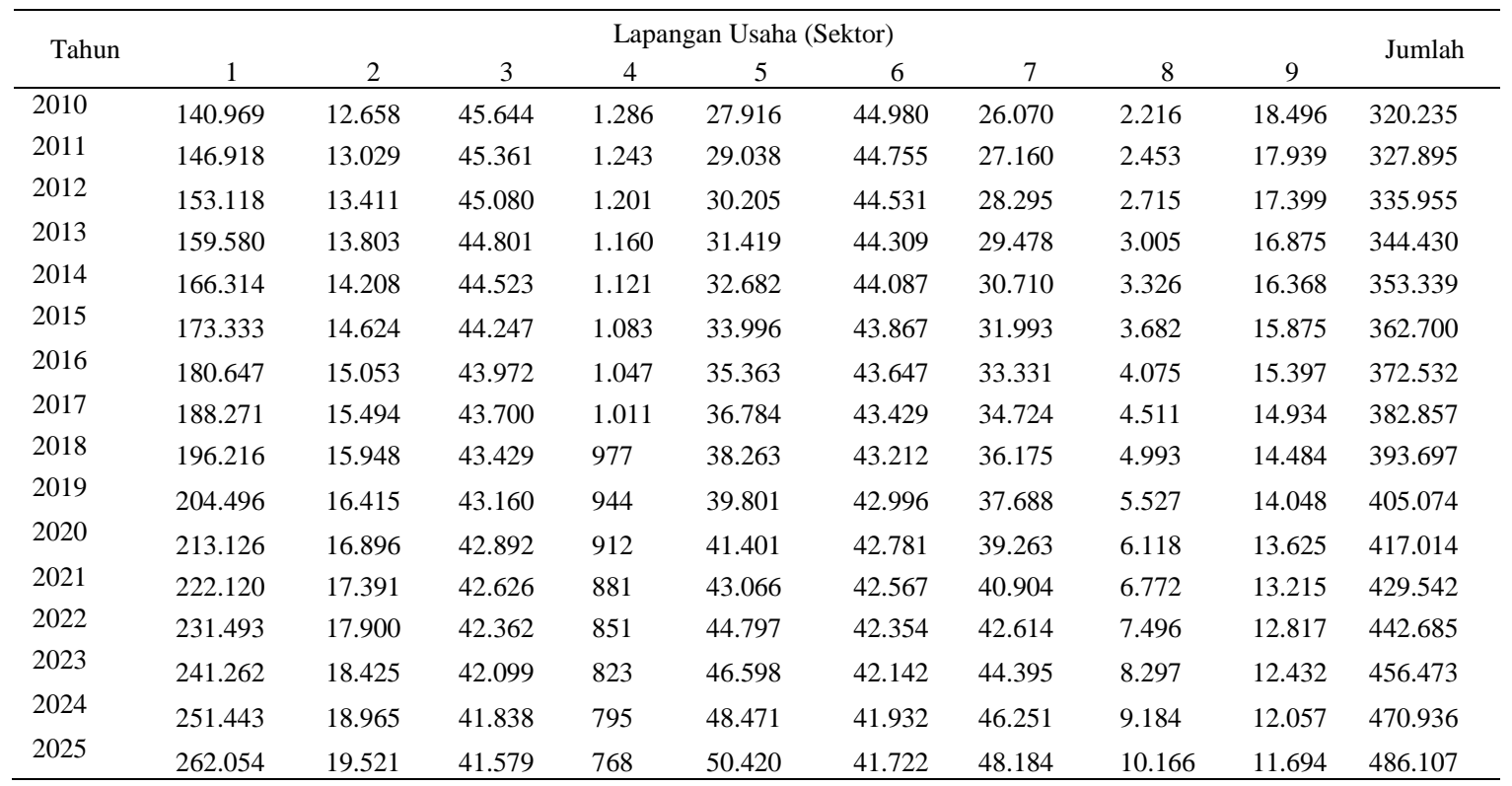

Sumber: BPS Lombok Barat Yang Telah disusun dan diolah kembali,Okt 2008

Keterangan :

1=Sektor Pertanian; 2=Sektor Pertambangan; 3=Sektor Industri; 4=Sektor Listrik, Gas dan Air; 5=Sektor

Konstruksi; 6=Sektor Perdagangan; 7=Sektor Komunikasi; 8=Sektor Keuangan; 9=Sektor Jasa

Tabel 2. Pendekatan Produktivitas Produktivitas Tenaga Kerja Sektoral di Kabupaten Lombok Barat Tahun 1997-2006

\begin{tabular}{|c|c|c|c|c|c|c|c|c|c|c|c|}
\hline Lapangan usaha (sektor) & 1997 & 1998 & 1999 & 2000 & 2001 & 2002 & 2003 & 2004 & 2005 & 2006 & $\begin{array}{c}\text { Perkemban } \\
\text { gan }(\%)\end{array}$ \\
\hline 1. Pertanian & $.583,82$ & $.540,40$ & $.716,22$ &, 97 & ,94 &, 13 &, 35 & ,39 &, 19 & $.583,82$ & $(16,14)$ \\
\hline 2. Pertambangan \& Penggalian & $.522,11$ & $.200,43$ & $.021,84$ &, 77 &, 09 &, 22 &, 40 &, 84 & ,08 & $.522,11$ & $(11,36)$ \\
\hline 3. Industri & 87,71 & 43,57 & 78,70 &, 37 &, 47 &, 56 &, 67 &, 17 &, 65 & 87,71 & $(5,61)$ \\
\hline 4. Listrik, Gas \& Air Bersih & $.486,83$ & 93,36 & 35,51 &, 55 &, 73 &, 91 &, 08 & 6,04 & 3,19 & $.486,83$ & 75,94 \\
\hline 5. Konstruksi & $.199,95$ & $.900,49$ & 699,10 & ,93 &, 36 &, 66 &, 15 &, 77 & ,90 & $.199,95$ & $(14,42)$ \\
\hline $\begin{array}{l}\text { 6. Perdagangan, Hotel \& } \\
\text { Restoran }\end{array}$ & $.646,28$ & $.452,65$ & $.943,12$ &, 77 &, 17 &, 34 &, 51 & ,96 & ,96 & $.646,28$ & $(10,99)$ \\
\hline 7. Angkutan \& Komunikasi & $.240,96$ & $.017,70$ & $.703,25$ &, 56 &, 89 &, 28 & ,64 & 1,38 &, 87 & $.240,96$ & $(12,29)$ \\
\hline $\begin{array}{l}\text { 8. Keuangan, Persewaan \& Jasa } \\
\text { Perusahaan }\end{array}$ & $0.925,4$ & $0.566,9$ & $2.226,7$ & 07,2 & 6,32 & 09,2 & 03,2 & 3,78 & 9,62 & $0.925,5$ & $(25,55)$ \\
\hline 9. Jasa-Jasa & $.027,51$ & $.871,57$ & $.838,36$ & ,94 &, 95 &, 11 &, 11 & 0,78 &, 23 & $.027,51$ & $(11,78)$ \\
\hline
\end{tabular}

Sumber : BPS Kabupaten Lombok Barat yang disusun dan diolah kembali dari Tabel 4 dan 9,Oktober 2008

Jumlah kesempatan kerja dari masing-masing sektor, untuk sektor industri mengalami penurunan 41.579 jiwa, untuk sektor jasa 11.694 jiwa dan 
yang paling dikhawatirkan adalah sektor listrik 768 jiwa.

Untuk jumlah kesempatan kerja yang paling tertinggi diperkirakan pada tahun 2025 sebesar 486.107 jiwa dan jumlah kesempatan kerja paling terkecil di tahun 2010. Jika dilihat dari tahun ke tahun maka jumlah kesempatan kerja akan mengalami peningkatan atau kecenderungan slopenya pisitif (Tren Positif).

Produktivitas sektoral dapat dihitung dari membagi PDRB dengan kesempatan kerja yang terserap disektor tersebut. Dari seluruh sektor lapangan usaha yang mempunyai produktivitas tertinggi adalah sektor Listrik, Gas dan Air mengalami pertumbuhan nilai tambah dari tahun 1997 sampai dengan tahun 2006 yaitu sebesar 75,94\% lebih tinggi dibandingkan dengan sektor lainnya dan yang terpenting adalah bahwa nilai tambahnya selalu meningkat dari tahun ke tahun. Ini menandakan bahwa sektor-sektor yang telah disebutkan di atas mampu menyerap tenaga kerja lebih banyak lagi.

Untuk sektor pertanian meskipun penyerapan tenaga kerjanya tinggi namun dari tahun ke tahun produktivitasnya cenderung menurun, begitu pula untuk sektor pertamabangan, sektor industri, sektor bangunan, sektor angkutan, Sektor keuangan dan sektor jasa mengalami penurunan, terlihat pada tabel 13. Hal ini mencerminkan sektor pertanian maupun sektor lainnya sudah tidak mampu untuk menyerap tenaga kerja lebih banyak. Kalaupun dipaksakan hasil yang diperoleh per orang yang bekerja tidak semakin bertambah tetapi semakin menurun.

Yang perlu diperhatikan dalam peningkatan produktivitas adalah peningkatan mutu dan kemampuan tenaga kerja. Peningkatan mutu dan produktivitas tenaga kerja di Kabupaten
Lombok Barat dilaksanakannnya berbagai kegiatan motivasi, penyuluhan, pendidikan dan pelatihan yang terarah terpadu dan menyeluruh. Pembinaan pendidikan dan pelatihan tenaga kerja disesuaikan dengan perkembangan kebutuhan pasar tenaga kerja serta kemajuan ilmu pengetahuan dan teknologi. Pelaksanaan pendidikan dan pelatihan lebih ditekankan pada peningkatan kualitas tenaga kerja terlatih dari kuantitasnya, dengan memperbanyak jam paket pendidikan dan latihan.

Untuk mencapai hasil yang optimal dalam pelaksanaan program pembangunan baik bersifat sektoral maupun regional, besarnya jumlah penduduk Kabupaten Lombok Barat dapat dijadikan sumber yang potensial bagi pertumbuhan dan perkembangan pembangunan daerah. Oleh karena itu penyediaan tenaga kerja perlu direncanakan agar kesenjangan antara tersedianya tenaga kerja dengan kesempatan kerja yang ada tidak terlalu besar.

Pada sisi tenaga kerja ini akan dibahas mengenai besarnya penyediaan tenaga kerja yaitu jumlah orang yang tersedia, mampu dan mau melakukan pekerjaan tanpa mengabaikan faktorfaktor lain yang mempengaruhi seperti jumlah penduduk serta pertambahannya, penyebaran penduduk, pendidikan dan lain-lain.

Perhitungan perkiraan jumlah penduduk, angkatan kerja dan angkatan kerja tertampung di Kabupaten Lombok Barat ini menggunakan rumus dasar sebagai berikut :

$\mathrm{P}_{\mathrm{n}}=\mathrm{P}_{0}(1+\mathrm{r})^{\mathrm{n}}$

$\mathrm{P}_{\mathrm{n}} \quad$ : Jumlah Penduduk pada tahun $\mathrm{n}$

$\mathrm{P}_{0} \quad$ : Jumlah Penduduk pada tahun dasar

r : Tingkat Pertumbuhan

n : Jangka Waktu 
Tabel 3. Perkiraan Jumlah Penduduk, Angkatan Kerja, Angkatan Kerja Tertampung dan Pencari Kerja di Kabupaten Lombok Barat Tahun 2010-2025

\begin{tabular}{|c|c|c|c|c|}
\hline \multirow{3}{*}{ Tahun } & \multicolumn{4}{|c|}{ Uraian } \\
\hline & Jumlah & Angkatan & Angkatan Kerja & Pencari \\
\hline & Penduduk & Kerja & Tertampung & Kerja \\
\hline 2010 & 850.634 & 5.975 & 5.130 & 1.037 \\
\hline 2011 & 864.840 & 6.586 & 5.851 & 1.042 \\
\hline 2012 & 879.282 & 7.260 & 6.674 & 1.047 \\
\hline 2013 & 893.966 & 8.003 & 7.612 & 1.053 \\
\hline 2014 & 908.896 & 8.821 & 8.683 & 1.058 \\
\hline 2015 & 924.074 & 9.724 & 9.903 & 1.064 \\
\hline 2016 & 939.506 & 10.718 & 11.296 & 1.069 \\
\hline 2017 & 955.196 & 11.815 & 12.884 & 1.074 \\
\hline 2018 & 971.148 & 13.024 & 14.696 & 1.080 \\
\hline 2019 & 987.366 & 14.356 & 16.762 & 1.085 \\
\hline 2020 & 1.003 .855 & 15.825 & 19.118 & 1.091 \\
\hline 2021 & 1.020 .619 & 17.443 & 21.807 & 1.097 \\
\hline 2022 & 1.037 .664 & 19.228 & 24.873 & 1.102 \\
\hline 2023 & 1.054 .993 & 21.195 & 28.370 & 1.108 \\
\hline 2024 & 1.072 .611 & 23.363 & 32.358 & 1.113 \\
\hline 2025 & 1.090 .524 & 25.753 & 36.908 & 1.119 \\
\hline
\end{tabular}

Sumber : BPS Lombok Barat disusun dan diolah kembali, Oktober 2008

\section{Catatan :}

Tahun dasar adalah tahun 2007 untuk Jumlah penduduk dan tahun dasar untuk angkatan kerja, angkatan kerja tertampung serta pencari kerja adalah tahun 2006. Tingkat pertambahan penduduk sebesar $1,67 \%$; Tingkat pertambahan angkatan kerja sebesar $10,23 \%$; Tingkat pertambahan angkatan kerja tertampung sebesar $14,06 \%$ serta Pencari kerja sebesar $0,51 \%$. Penduduk (P) dapat diganti dengan angkatan kerja (AK), angkatan kerja tertampung (AKT) dan Pencari Kerja (PK).

Berdasarkan hasil perhitungan pada tabel dibawah diperoleh perkiraan jumlah penduduk, angkatan kerja, angkatan kerja tertampung di Kabupaten Lombok Barat.

Dari tabel 3 dapat diketahui bahwa jumlah penduduk Kabupaten Lombok Barat pada tahun 2010 adalah sebesar 830.634 jiwa yaitu naik sebesar 34.527 jiwa dari tahun sebelumnya. Untuk tahun 2025 diperkirakan jumlah penduduk Kabupaten Lombok Barat sebesar 1.090 .524 jiwa.

Dari sekian jiwa tersebut jumlah angkatan kerja tahun 2025 diperkirakan meningkat hingga 25.753 jiwa, untuk angkatan kerja tertampung meningkat juga hingga 36.908 jiwa serta pencari kerja juga bertambah hingga 1.119 jiwa atau naik sebesar $143 \%$ dari angkatan kerja. Jika dilihat dari perkembangan penduduk lebih pesat dibandingkan dengan angkatan kerja, angkatan kerja tertampung dan pencari kerja. Hal ini dapat diakibatkan faktor-faktor pendukung dari luar yakni adanya pelatihan sumber daya manusia yang dibuat dari berbagai instansi terkait. Oleh karena itu perlu adanya kerjasama antara pemerintah daerah dengan pihak lain dalam mengembangkan dibidang pendidikan, penambahan keterampilan dan lain sebagainya yang berkaitan dengan peningkatan sumber daya manusia dan mutu dari sumber daya yang ada di daerah dapat bersaing dengan daerah lainnya.

Dengan masih banyaknya jumlah penduduk yang dapat dimanfaatkan untuk perkembangan daerah tentunya masih berat pula beban pemerintah daerah setempat agar tidak ada terjadi ketimpangan yang berakibat fatal bagi daerah Kabupaten Lombok Barat sendiri. Pendidikan adalah salah satu cara agar sumber daya manusia dapat berkembang 
sesuai dengan jaman. Jika satu ini dapat terus dijalankan maka kedepan atau tahun 2010-2025 jumlah angkatan kerja, angkatan kerja tertampung, dan pencari kerja diharapkan seimbang antara permintaan tenaga kerja maupun dengan penawaran akan tenaga kerja tersebut.

\section{PENUTUP}

Dari hasil-hasil perhitungan dan penelitian serta uraian-uraian yang telah disajikan dalam bab-bab terdahulu maka dapat diambil kesimpulan Dalam periode 1997-2006 laju pertumbuhan PDRB nonmigas tercatat sebesar 2.76 persen. Sektor yang menunjukkan pertumbuhan peningkatan adalah sektor listrik, gas dan air minum 6.53 persen; sektor pengangkutan dan komunikasi 5.9 persen; sektor industri pengolahan 4.25 persen; serta sektor bangunan 4.54 persen. PDRB nonmigas per kapita pada tahun 2006 berdasarkan harga konstan 1996 di Kabupaten Lombok Barat mencapai Rp 1,987,449.56. Dibandingkan dengan angka tahun 2005 yang besarnya $\mathrm{Rp} 1,881,424.64$, terjadi peningkatan dengan laju pertumbuhan rata-rata 0.11 persen per tahun.

Pertumbuhan tenaga kerja Kabupaten Lombok Barat periode 19972006. Pertumbuhan tenaga kerja Kabupaten Lombok Barat tertinggi terjadi pada tahun 1999 sebesar 16,59\%, sedangkan penurunan yang signifikan terjadi pada tahun 2006 sebesar $-9,40 \%$ dan tahun 2004 sebesar $-6,03 \%$ sedangkan secara rata-rata pertumbuhan Kabupaten Lombok Barat sebesar 2,29 $\%$ pertahun. Jumlah angkatan kerja mengalami perkembangan rata-rata $10,23 \%$ per tahun, sedangkan angkatan kerja tertampung perkembangan rata-rata per tahunnya sebesar 14,06\%. Dilihat dari perbandingan antara angkatan kerja dengan angkatan kerja tertampung pada tahun 2006, jumlah angkatan kerja sebanyak 4.047 orang dan angkatan kerja tertampung sebanyak 3.031 orang, ini berarti angkatan kerja yang tertampung oleh sektor-sektor pembangunan di Kabupaten Lombok Barat mencapai $75 \%$ dari total angkatan kerja yang ada.

Struktur ekonomi di Kabupaten Lombok Barat masih agraris karena sektor pertanian mendominasi proporsi kesempatan kerja yang ada di Kabupaten Lombok Barat. Hingga akhir Tahun 2006, kesempatan kerja terbesar masih didominsi oleh lapangan usaha pertanian yaitu pada tahun 1997 mencapai 31,83\% dari sektor-sektor lainnya, sampai tahun 2006 menjadi 40,74\%. Sedangkan tahun 2025 diperkiraan kesempatan kerja sektor pertanian masih memegang peranan penting atau mengalami tren yang positif. Sedangkan perkiraan kesempatan kerja terkecil ada pada sektor listrik,air dan gas yang mengalami penurunan atau tren negatif. Sektorsektor lainnya yang cukup menonjol adalah sektor perdagangan, jasa dan industri. Ini menujukkan bahwa perluasan kesempatan kerja belum merata di seluruh sektor lapangan usaha.

Untuk sektor pertanian meskipun penyerapan tenaga kerjanya tinggi namun dari tahun ke tahun produktivitasnya cenderung menurun. Begitu pula untuk sektor keuangan yang mengalami penurunan cukup tajam. Hal ini mencerminkan sektor pertanian maupun keuangan sudah tidak mampu untuk menyerap tenaga kerja lebih banyak lagi. Kalaupun dipaksakan hasil yang diperoleh per orang yang berkerja tidak akan semakin bertambah tetapi akan semakin menurun. Demikian pula untuk sektor angkutan, jasa dan perdagangan yang juga mengalami penurunan produktivitas tiap tahunnya. Untuk sektor Listrik mengalami perkembangan produktivitasnya tinggi atau mengalami tren yang positif yakni sebesar $75.94 \%$. Perlu diketahui 
peningkatan tenaga kerja memang tidak terjadi pada sektor ini melainkan ada faktor lain yang membuat meningkat antara lain pelanggan atau konsumen yang menggunakan jasa ini lebih banyak dari biasanya.

\section{DAFTAR PUSTAKA}

Budi, Purbayu S dan Hamdani M. 2007. Statistik Deskriftif dalam Bidang Ekonomi dan Niaga: PT. Erlangga. Jakarta

Effendi, Tadjudin Noer. 1985. Urbanisasi Pengangguran Dan Sektor Informal Di Kota: PT Gramedia. Jakarta

Faisal, Sanapiah. 1990. Penelitian Kualitatif Dasar - Dasar Dan Aplikasi. Malang

Kustituanto, Bambang dan Badrudin, Rudy. 1995. Statistika Ekonomi 1. STIE. Yogyakarta

Manulang sendjun H, 1990. Pokokpokok hukum ketenagakerjaan indonesia. Rineka cipta. Jakarta

Moleong, Lexy. J. 1994. Metodologi Penelitian Kualitatif. PT Remaja Rosdakarya. Bandung.

Simanjuntak, Payaman. J. 1985. Pengantar Ekonomi Sumber Daya Manusia. FE UI. Jakarta

Suharsimi, Arikunto. 1989. Prosedur Penelitian Suatu Pendekatan Praktek. Bina Aksara. Jakarta

Suharyadi dan Purwanto. 2003. Statistika Untuk Ekonomi dan Keuangan Modern (Buku I). Salemba Empat. Jakarta.
Surakhmad, Winarno. 1985. Pengantar Penelitian Ilmiah Dasar Dan Metode Teknis. Bandung

Suroto. 1986. Strategi Pembangunan Dan Perencanaan Tenaga Kerja. UGM Press. Yogyakarta

Sumarsono, Sonny. 2003.Ekonomi Manajemen Sumberdaya Manusia dan Ketenagakerjaan. Graha Ilmu. Yogyakarta.

Waluyo, Dwi Eko. 2007. Makalah Usulan Penelitian Training Metpen IESP. UMM. Malang 